\title{
PERFORMANCE OF A POLY-GREENHOUSE COVERED BY DOUBLE LAYERS OF POLYETHYLENE WITH AIR GAP
}

\author{
H. S. Abdel-Galil*
}

\section{ABSTRACT}

Two similar experimental poly-greenhouses were used in this study. The first one was covered by double layers of polyethylene with 8-cm air gap and the second one was covered by double layers of polyethylene stick to each other. The experiments were carried out to study the effect of using double layers of polyethylene with air gap on the energy transport characteristics and most relative vegetative growth parameters and production of a tomato crop under Fayoum depression climatic conditions (Egypt). Hybrid variety (ALZAIN F1, seeds) of tomato seeds were germinated under poly-greenhouses and one-month-old seedlings (120mm length and six leaves approximately) were transplanted in both polygreenhouses. The obtained results indicated that using $63 \%$ shading cover for both greenhouses (in summer months) resulted in reduction of solar radiation by $69.2 \%$ and $72.4 \%$ inside the first greenhouse (G1) and the second greenhouse (G2), respectively. The greatest value of cooling effect $\left(11.86{ }^{\circ} \mathrm{C}\right)$ and effectiveness of evaporative cooling system $(73.85 \%)$ were achieved inside the first greenhouse (G1), which covered by double layers of polyethylene with 8-cm air gap, whereas, the cooling effect $\left(9.19^{\circ} \mathrm{C}\right)$ and effectiveness of cooling system (67.57\%) occurred inside the second greenhouse (G2), which covered by double layer of polyethylene without air gap. The first Greenhouse (G1) increased the temperature of cold air just leaving the cooling system by $3.86{ }^{\circ} \mathrm{C}$, while the second greenhouse (G2) increased the interior ambient air temperature by $5.46^{\circ} \mathrm{C}$. Thus, the first greenhouse (G1), on the average, increased the rate of vegetative growth by $11.5 \%$, and fresh yield of tomato crop by $34.39 \%$ comparing with the second greenhouse (G2).

\section{INTRODUCTION}

reenhouses are required for crop production in Egypt during
summer and winter periods. It can provide a suitable
environment that will result in improving crop growth and

* Assist. Prof. of Agric. Eng., - Fac. of Agric.- Fayoum University. 
air temperature, air relative humidity, light, and soil nutrients) has been suggested for commercial crops since it could promise increased yields, better quality, and production stability of high value crop species.

Heinemann and Walker (1987) reported that the choice of greenhouse cover material is strongly dependent upon several factors; solar radiation transmission, resistance of ultraviolet (UV) degradation, heat losses, initial purchase price, and installation cost. Lau and Staley (1989) indicated that computer runs using long term average solar radiation data revealed that, the greenhouse shape and cover material had an obvious effect on the effective transmissivity of the greenhouse. Nelson 1990 and Takakura et al. (1994) indicated that research efforts along two paths: (a) improving the greenhouse structure to reduce energy losses, while maintaining a desirable growth environment; and (b) developing alternate energy sources such as solar, wind, reject heat from power plants, geothermal energy, and any other source to meet greenhouse heating demand. Papadakis et al. (1996) reported that mechanical ventilation is not economic because of its cost in term of energy use and maintenance. Natural ventilation is a cheap, practical method and very commonly method used to ensure a near optimal greenhouse climate during both summer and winter. Elsner et al. (2000) reported that greenhouses are required to allow high light transmittance, low heat consumption, sufficient ventilation efficiency, adequate structural strength and good overall mechanical behavior, low construction and operating costs. The design of a greenhouse aims at exploiting the external climatic conditions for improving the indoor microclimate. For this reason, the overall greenhouse design is strongly influenced by the climate and the latitude of the location. Al-Amri (2000) reported that the dramatic decreasing in the ambient air temperature (particularly at night) during winter season and vice versa in summer season may be considered as one of the biggest problem in Saudi Arabia's greenhouse vegetable production industry.

El-Batawi et al. (2004) indicated that tomato is a warm season crop requiring a temperature from $15^{\circ} \mathrm{C}$ to $30^{\circ} \mathrm{C}$. Kenneth et al. (2005) found that tomato seedlings germinated under controlled greenhouse conditions were closed to the same shape, size, length and color and more resistance to diseases than the field germinated tomatoes seedlings. 
Abdel-Ghany et al. 2006) indicated that the radiation transmission through a covering material is affected by several factors including: type of covering material, dirtiness, dust deposition, and changes in color caused by aging, location, and incident angle of the radiation. Another factor which determines the transmittance of a greenhouse covering is the presence of condensate on the interior surface of the materials. Temperature of the greenhouse cover is an essential parameter needed for any analysis of energy transfer in the greenhouse. Measuring the correct value of it is difficult due to the transparency of the covering materials and the effects of solar and thermal radiation and air movement on the cover surface. Al-Helal (2007) indicated that greenhouse ventilation is a necessary process to remove solar radiation heat, to control the level of relative humidity, and to replenish carbon dioxide that plants consume during the daylight hours in the process of photosynthesis. Wikipedia (2007) reported that one of the most aspects of greenhouse design is to provide a covering with controlled differences between the transparency in the solar radiation band ( $280 \mathrm{~nm}$ to $2500 \mathrm{~nm}$ wavelengths) and the terrestrial thermal radiation band (5000 $\mathrm{nm}$ to $35000 \mathrm{~nm}$ ) for the purpose of either raising or lowering the temperature inside the greenhouse. Alhamdan and Al-Helal (2009) indicted that polyethylene as a greenhouse covering material is low in cost, light weight, easy to apply. Unfortunately, it also has a high light transmittance and thermal conductivity. However, polyethylene films as a greenhouses covering materials with its transparent characteristics that transmits visible light (400-700 nm), which is the main source of energy for photosynthesis. Furthermore, it is susceptible to mechanical failure due to harsh conditions of high temperature, solar radiation, and wind. Abdel-Galil (2010) found that poly-greenhouse covered only by black screen sheets (especially with $63 \%$ or $75 \%$ shading ratios) was found more suitable for better seedlings germination, plant growth and yield of tomato than this with $25 \%$ shading ratio and open field condition in the summer months.

Therefore, the aim of this study is to investigate the effect of covering methods on thermal performance and energy transport characteristics in greenhouses under Fayoum local climatic conditions, and their effect on 
the most relative vegetative growth parameters. The specific objectives of this study are to: (a) compare the traditional covering method (double layers of polyethylene) vs. (double layers separated with air gap), (b) study the effect of covering method on the thermal performance and energy transport characteristics for each case, and (c) study the effect of covering method on the most relative vegetative growth parameters and productivity.

\section{MATERIALS AND METHODS1.}

Experimental greenhouses: Two identical (Quonset-style) polygreenhouses at El-Azab village, which is located at $5 \mathrm{~km}$ south of Fayoum city, Egypt, (Latitude of $29.18^{\circ} \mathrm{N}$ and Longitude angle of $30.3^{\circ}$ ) were utilized to study the effect of using double layers of polyethylene cover with air gap on control environment inside the greenhouses. Also, these greenhouses were utilized to grow and produce tomato during the summer months of 2012. Each greenhouse had gross dimensions of 8.00 $\mathrm{m}$ long, $4.00 \mathrm{~m}$ wide, and $3.00 \mathrm{~m}$ height, with a net surface area of 32.00 $\mathrm{m}^{2}$. Water galvanized pipes (38.1 mm diameter) were used to form the structural frame of the two experimental greenhouses. Both greenhouses were covered by double layers of $200 \mu \mathrm{m}$ thick, 5.5\% UV polyethylene sheets with the following criteria:

- The first greenhouse (G1) was covered by double layers with an 8$\mathrm{cm}$ air gap of polyethylene.

- The second greenhouse (G2) was covered by double layers of polyethylene stick to each other.

Both greenhouses were covered with an external black-screen shade net sheet of $63 \%$ shading ratio, to study their performance under shading conditions, and their effects on meteorological conditions inside the greenhouses (ambient air temperature, $\mathrm{T}_{\mathrm{ai}}$, relative humidity, $\mathrm{Rh}_{\mathrm{i}}$ and internal light intensity, $\mathrm{L}_{\mathrm{i}}$ ) and on the growth of tomato plants. Both greenhouses were oriented in East-West direction and placed under the same operating conditions. To increase and maintain the durability of structural frame and polyethylene cover, tensile galvanized wires $(2.0 \mathrm{~mm}$ diameter) were tied and fixed throughout the pipes and the curvatures of the greenhouses frames. The schematic diagram of both greenhouses is illustrated in Fig. (1). 


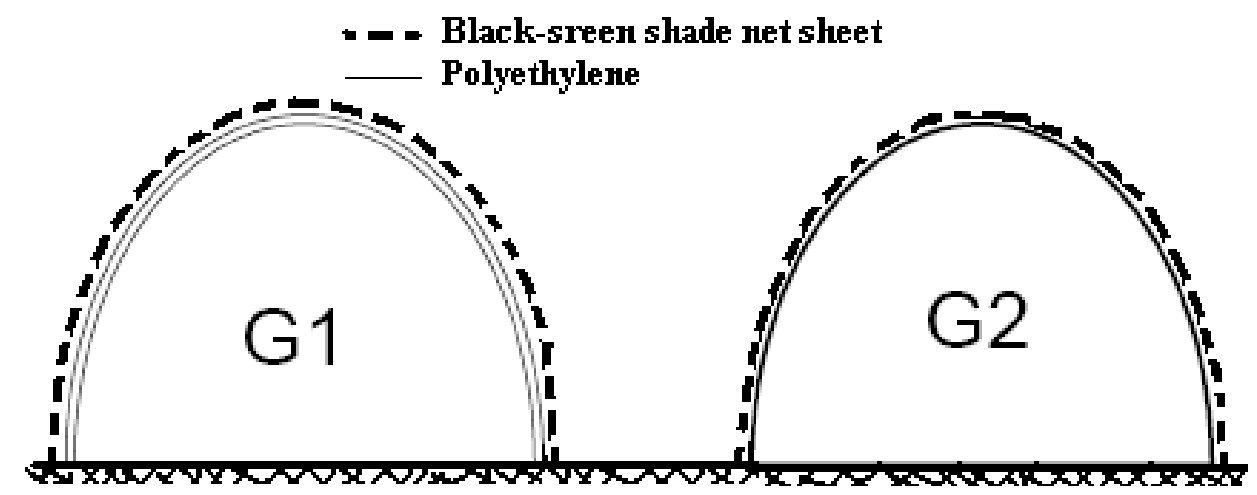

(a) Double layers of polyethylene (b) Double layers of polyethylene with 8-cm air gap. without air gap.

Fig. (1): Types of Greenhouses Covering Methods.

2. Meteorological measurements and Instrumentation: Solar radiation intensity $\left(\mathrm{I}, \mathrm{W} \cdot \mathrm{m}^{-2}\right)$, air temperature $\left(\mathrm{T},{ }^{\circ} \mathrm{C}\right)$, and relative humidity $(\mathrm{Rh}$, $\%)$ were measured daily from sunrise to sunset inside and outside the two greenhouses. The solar radiation flux incident on a horizontal surface was measured using a data acquisition system (TENMARS - Solar Power Meter TM-206), with a measurement of 0.0 to $1999 \mathrm{~W} \cdot \mathrm{m}^{-2}$ and an accuracy of $0.1 \mathrm{~W}$. $\mathrm{m}^{-2}$ over a spectral range of 300 to $1100 \mathrm{~nm}$. Data were collected daily by a data logger at each $10 \mathrm{~min}$. and averaged over a time of $1 \mathrm{hr}$. interval. Temperature and relative humidity inside and outside the greenhouses were measured using a TENMARS-TM305-Temperature/Rh Datalogger-(TENMARS ELECTRONICS CO., NEIHU, TAIWAN) and the specifications of this device are shown in Table (1). The air temperature and relative humidity were recorded daily for the period of study. Data were recorded at each $10 \mathrm{~min}$. by the data-logger and averaged over a time of $1 \mathrm{hr}$. interval. Inside each greenhouse, there are three measured positions (Center of the greenhouse ( $\mathrm{Ti}_{2}$ ) and one meter far from the greenhouse doors (Ti1 and Ti3)). The temperature and relative humidity sensors were placed in multi-plate radiation shields above the ground by one meter to protect them from error-producing by solar radiation and precipitation. 
BIOLOGICAL ENGINEERING

Table (1): Specifications of temperature and humidity data-logger.

\begin{tabular}{|c|c|c|}
\hline \multirow{2}{*}{ Item } & \multicolumn{2}{|c|}{ Specifications } \\
\cline { 2 - 3 } & Temperature & Humidity \\
\hline $\begin{array}{c}\text { Measurement } \\
\text { Range }\end{array}$ & $-40{ }^{\circ} \mathrm{C}$ to $85^{\circ} \mathrm{C}$ & $1 \%$ to $99 \%$ \\
\hline Accuracy & $\pm 0.6^{\circ} \mathrm{C}$ from- $-20^{\circ} \mathrm{C}$ to $50^{\circ} \mathrm{C}$ & $\pm 3.0 \% \mathrm{RH}(20 \% \sim 80 \%)$ \\
& $\pm 1.0^{\circ} \mathrm{C}$ for all other ranges & $\pm 5.0 \% \mathrm{RH}(<20 \%,>80 \%)$ \\
\hline Resolution & $0.1^{\circ} \mathrm{C}$ & $0.1 \%$ \\
\hline Type & - & Capacitor \\
\hline
\end{tabular}

3. Design of Evaporative Cooling System: Evaporative cooling system was designed and employed throughout the experimental work. It mainly based on the process of heat absorption during the evaporation of water. It mainly consists of cooling pads and extracting fans. A fluted cellulose pad was mounted in a vertical fashion at the end of each polygreenhouse. A polyvinyl chloride pipe (0.5 inch diameter) was suspended immediately above the cooling pads and small holes were drilled each 10 $\mathrm{cm}$ long throughout its length, and the end of this pipe was capped. A baffle was placed below the water pipe to spread the water uniformly before it drops onto the cooling pads, A 600 liters water tank was used as a main source, to supply the evaporative cooling system by the amount of water required for its operations. To collect the water dropped from the pads and return it into the main water tank, a water sump was mounted under the pads from which it could be recycled to the cellulose pads by means of the water pump. The cooling pads were placed $20-\mathrm{cm}$ above the ground surface of the greenhouse to bring the cold air onto the plants throughout the growth period. Two extracting fans (each $50-\mathrm{cm}$ dia., single speed, directs driven and $3630 \mathrm{~m}^{3} \cdot \mathrm{hr}^{-1}$ discharge) were located on the leeward side of the greenhouses and the pads on the side toward the prevailing wind (opposite side of the extracting fans). The schematic diagram of the evaporative cooling system is illustrated in Fig. (2). The extracting fans were automatically operated using a differential thermostat. They are switched "ON" when the interior air temperature of the poly-greenhouse reaches $25^{\circ} \mathrm{C}$, and switched "OFF" when it was lower than $25^{\circ} \mathrm{C}$. 


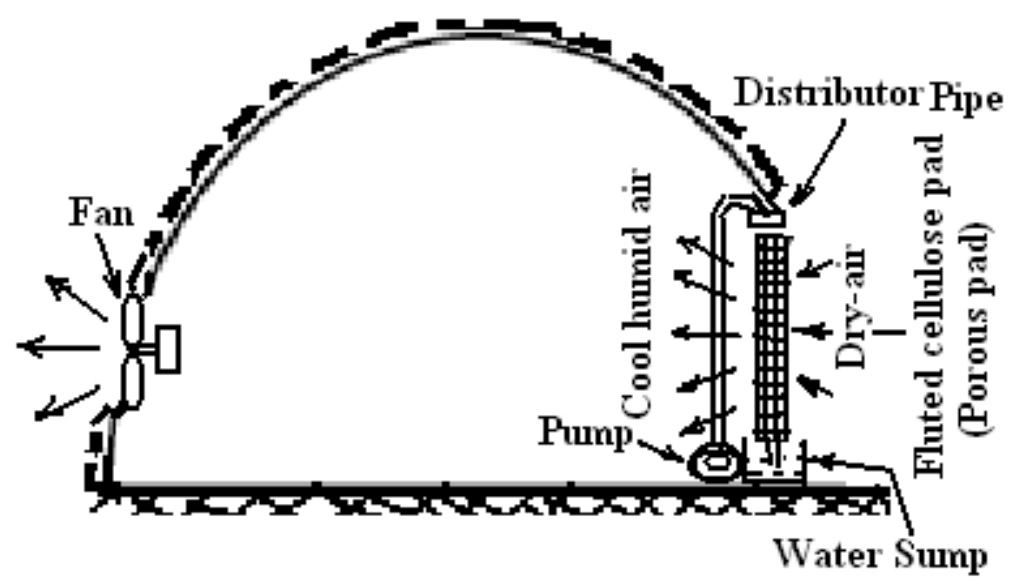

Fig. (2): The evaporative cooling system.

Potable water (drinking water) was usually used in the evaporative cooling system to prevent the accumulation of salt on the cellulose pads. In the summer months (hot climate of Fayoum depression), evaporative cooling systems have been commonly employed to reduce the interior air temperature of both greenhouses. Evaporative cooling system efficiency (ท́) is defined according to (ASHRAE, 1989) as follows:

$$
\dot{\eta}=\frac{T_{o d b}-T_{i d b}}{T_{o d b}-T_{o w b}} \times 100=\frac{T_{d d}}{T_{w d}} \times 100
$$

Where:

$$
\begin{aligned}
& \mathrm{T}_{\mathrm{odb}}=\text { dry-bulb temperature of exterior air, } \quad{ }^{\circ} \mathrm{C} \\
& \mathrm{T}_{\mathrm{idb}}=\text { dry-bulb temperature of interior air, } \quad{ }^{\circ} \mathrm{C} \\
& \mathrm{T}_{\text {owb }}=\text { wet-bulb temperature of exterior air, } \quad{ }^{\circ} \mathrm{C} \\
& \mathrm{T}_{\mathrm{dd}}=\text { cooling effect }=\mathrm{T}_{\mathrm{odb}}-\mathrm{T}_{\mathrm{idb}}, \\
& \mathrm{T}_{\mathrm{wd}}=\text { wet-bulb depression }=\mathrm{T}_{\text {odb }}-\mathrm{T}_{\text {owb }},{ }^{\circ} \mathrm{C}
\end{aligned}
$$

4. Design of Irrigation System: A drip irrigation system was designed and employed throughout the experimental work. It mainly consisted of five components: (a) main water supply tank, (b) fertilizer tank, (c) polyvinyl chloride pipes (PVC), (d) water pump, and (e) drippers. An eighty liter fertilizer tank (cylindrical form) was placed in the line of the watering system to mix chemical fertilizers with irrigation water before it passes through the drippers. A pipe (1.0 inch dia.) was used as a main source to distribute the irrigation water uniformly for the two 
greenhouses. Twenty drippers (0.375 inch dia.) were uniformly distributed alternatively (with $50 \mathrm{~cm}$ drippers spacing) throughout each row of plants using lateral rubber pipe ( 0.5 inch dia., and $3.785{\mathrm{~L} . \mathrm{h}^{-1}}^{-1}$ discharges). In order to conserve the irrigation water, the watering system was pumped and run only thirty minutes a day throughout the experimental work.

5. Factors Affecting Tomato Production: The production of protected cropping depends on environmental parameters which are generally recognized to have a major impact on its growth, flowering and fruiting period. These parameters have been included ambient air temperature, air relative humidity, light, air movement, and solar radiation intensity. For the duration of the experimental work (one season per year), the stem length and the total fresh yield of tomato crop will monitored and compared between both treatments. Statistical analyses are used for comparison between the treatments and to clarify the effect of the two different treatments on the tomato crop. Hybrid variety (ALZAIN F1, seeds) of tomato seeds were germinated under poly-greenhouses and onemonth-old seedlings (120-mm length and six leaves approximately) were transplanted in both poly-greenhouses.

\section{RESULTS AND DISCUSSIONS}

The following items may be appearing the thermal behavior inside the greenhouse affected by using double cover with air gap under Fayoum climatic conditions.

1. Hourly average total solar radiation: The hourly average total solar radiation incident on the horizontal surface and the amount of it transmitted into the greenhouses cover during the day-time of the experiment period were recorded. Relationships between averaged solar radiation outside and inside the two greenhouses were plotted as shown in Fig. (3). The plotted data were taken as the average of data, which collected from sunrise to sunset. It's clear that, the hourly average solar radiation available inside both greenhouses reached the maximum magnitude at and around noon-time and it was less compared with the hourly average solar radiation flux incident on the outside horizontal surface. Also, using 63\% shading cover for both greenhouses (in summer months) resulted in reduction of solar radiation by $69.2 \%$ and $72.4 \%$ 
inside the first greenhouse (G1) and the second greenhouse (G2), respectively. It's known that, as the solar radiation intensity (I) decreases the ambient air temperature $\left(\mathrm{T}_{\mathrm{a}}\right)$ decreases and thus, the interior air temperatures of the greenhouses decreases. Finally, using double layers with an air gap of polyethylene and external shading covers caused to decrease the transmission of solar radiation inside the greenhouse during the day-time from sunrise to sunset.

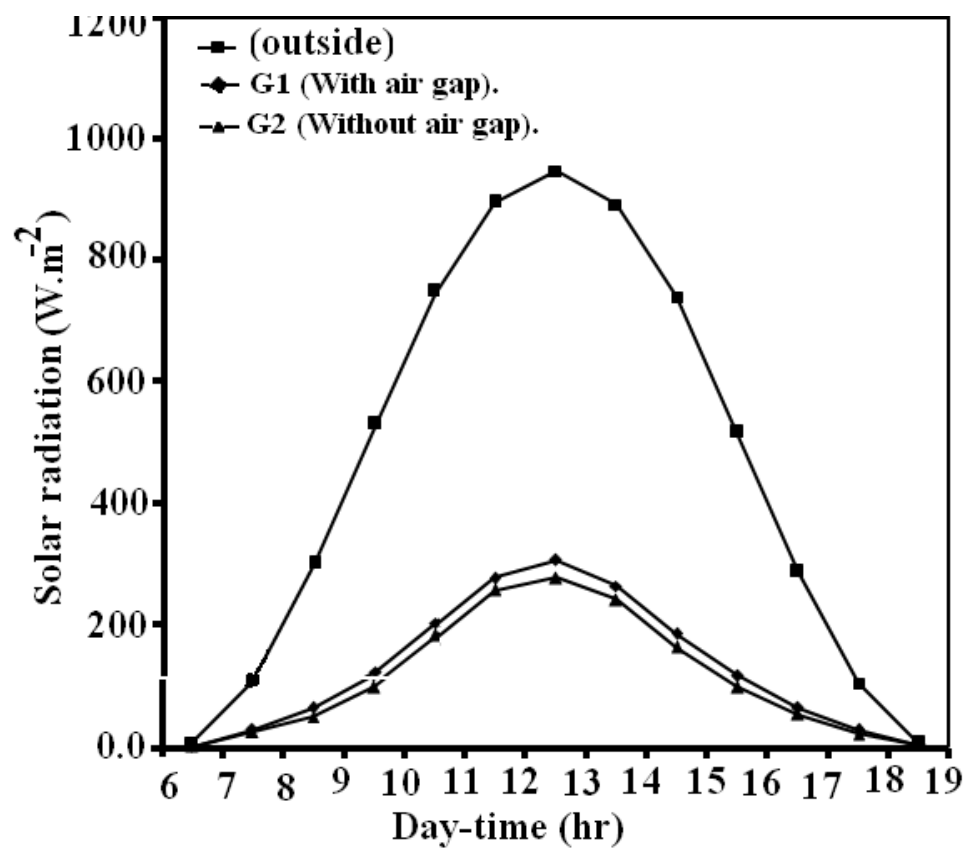

Fig. (3): Relationship beteewn incident solar radiatio outside and inside greenhouses (using 63\% shading cover).

2. Evaporative cooling system: Data obtained from this research work were recorded during the experimental period and summarized in Table (2). It's known that, as the solar radiation (I) increases the exterior ambient air temperature $\left(\mathrm{T}_{\text {ао }}\right)$ increases. Also, it clearly that, substantial decrease of greenhouses interior air temperatures occurred when the relative humidity outside the greenhouses decreased. Under these conditions, the evaporative cooling system provided a cooling effect (air temperature difference between outside and inside the greenhouse) of $10^{\circ} \mathrm{C}$ or more. To assess the most important parameters affecting effectiveness of evaporative cooling system, the ambient air temperature and wet-bulb 
depression were employed. The cooling effect and, consequently, the effectiveness of the evaporative cooling system were strongly affected by the wet-bulb depression (difference between dry and wet-bulb temperatures of exterior ambient air temperature, $\mathrm{T}_{\mathrm{a} o}$ ) that was affected mainly by air relative humidity. Therefore, all the data collected throughout the experimental work were examined to approach mathematical models (Fig.4).

The best fit equations relating the cooling effect $\left(\mathrm{T}_{\mathrm{dd}}\right)$ to the wet-bulb depression $\left(\mathrm{T}_{\mathrm{wd}}\right)$ for both greenhouses were:

$\mathrm{T}_{\mathrm{dd}}$ (Greenhouse with air gap, G1) $=2.7405+0.5681\left(\mathrm{~T}_{\mathrm{wd}}\right),[\mathrm{r}=0.975]$

$\mathrm{T}_{\mathrm{dd}}$ (Greenhouse without air gap, G 2) $=0.5481+0.6557\left(\mathrm{~T}_{\mathrm{wd}}\right),[\mathrm{r}=0.987]$ The greatest values of cooling effect $\left(11.86{ }^{\circ} \mathrm{C}\right)$ and effectiveness of evaporative cooling system $(73.85 \%)$ were achieved inside the greenhouse (G1) at the greatest value of wet-bulb depression $\left(16.06{ }^{\circ} \mathrm{C}\right)$ and lowest value of air relative humidity (46\%); while, the lowest value of cooling effect $\left(9.19^{\circ} \mathrm{C}\right)$ and effectiveness of cooling system $(67.57 \%)$ occurred inside the greenhouse (G2) at the lowest value of wet-bulb depression $\left(13.60{ }^{\circ} \mathrm{C}\right)$ and greatest value of air relative humidity $(55 \%)$. For the duration of the experimental work, the wet-bulb depression was found to be directly related to the exterior ambient air temperature, air relative humidity and saturation pressure of the air. Finally, we can say that, increasing the exterior ambient air temperature $\left(\mathrm{T}_{\mathrm{ao}}\right)$ and decreasing the ambient relative humidity caused to increase the saturation pressure and thus, making the cooling system more efficient.

Table (2): Daily Average Temperatures (T), Relative Humidity (RH)

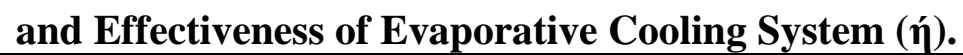

\begin{tabular}{|c|c|c|c|c|c|c|c|c|}
\hline \multirow{2}{*}{ Moth } & \multirow{2}{*}{ Greenhouse } & \multicolumn{5}{|c|}{ Temperatures, $\left({ }^{\circ} \mathrm{C}\right)$} & \multirow{2}{*}{$\begin{array}{l}\mathrm{RH} \\
(\%)\end{array}$} & \multirow{2}{*}{ 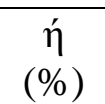 } \\
\hline & & $T_{\text {odb }}$ & $T_{\text {idb }}$ & $\mathrm{T}_{\text {owb }}$ & $\mathrm{T}_{\mathrm{wd}}$ & $\mathrm{T}_{\mathrm{dd}}$ & & \\
\hline May & G1 & \multirow{2}{*}{30.82} & 18.96 & \multirow{2}{*}{14.76} & \multirow{2}{*}{16.06} & 11.86 & \multirow{2}{*}{46} & 73.85 \\
\hline 2011 & $\mathrm{G} 2$ & & 19.41 & & & 11.41 & & 71.05 \\
\hline June & G1 & \multirow{2}{*}{32.24} & 21.72 & \multirow{2}{*}{17.86} & \multirow{2}{*}{14.38} & 10.52 & \multirow{2}{*}{53} & 73.15 \\
\hline 2011 & G2 & & 22.52 & & & 9.72 & & 67.59 \\
\hline July & G1 & \multirow{2}{*}{32.00} & 22.70 & \multirow{2}{*}{18.40} & \multirow{2}{*}{13.60} & 9.30 & \multirow{2}{*}{55} & 68.38 \\
\hline 2011 & G2 & & 22.81 & & & 9.19 & & 67.57 \\
\hline \multirow{2}{*}{ Mean } & G1 & \multirow{2}{*}{31.69} & 21.13 & \multirow{2}{*}{17.00} & \multirow{2}{*}{14.68} & 10.57 & \multirow{2}{*}{51.3} & 71.81 \\
\hline & G2 & & 21.58 & & & 10.11 & & 68.74 \\
\hline
\end{tabular}




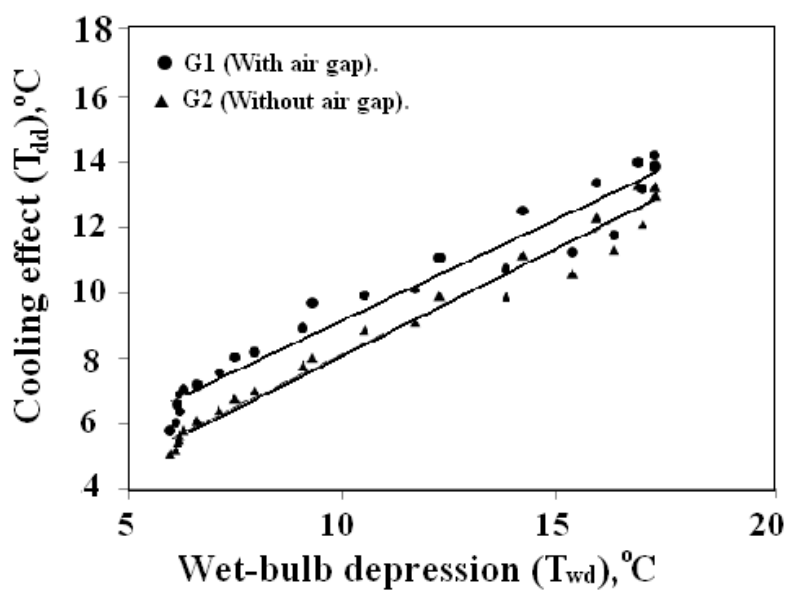

Fig. (4): Cooling effect versus wet-bulb depression

To examine the relationship between the interior air temperatures (Tai) for both poly-greenhouses and the exterior ambient air temperature $\left(\mathrm{T}_{\mathrm{a}}\right)$, air relative humidity (R.H.) and wet-bulb depression ( $\left.\mathrm{T}_{\mathrm{wd}}\right)$, multiple regression analysis was used. The interior air temperatures $\left(\mathrm{T}_{\mathrm{ai}}\right)$ for greenhouses (G1) and (G2) behaviors during the experimental months were plotted against the wet-bulb depression $\left(\mathrm{T}_{\mathrm{wd}}\right.$ ) as shown in Fig. (5). The plotted data was taken as the average of data, which collected from sunrise to sunset. Regression analysis revealed a highly significant linear relationship between these parameters for greenhouses (G1) and (G2). It also showed that, the differences between the intercepts and the slopes were highly significant $(\mathrm{P}<0.001)$. The regression equations obtained for both greenhouses were:

Tai (Greenhouse, G1) $=0.4780\left(\mathrm{~T}_{\mathrm{wd}}\right)+18.046 \quad, \quad[\mathrm{r}=0.893]$

Tai (Greenhouse, G2) $=0.4545\left(\mathrm{~T}_{\mathrm{wd}}\right)+19.702 \quad, \quad[\mathrm{r}=0.895]$

The evaporative cooling system effectiveness varied with day-time through every day and from greenhouse to another throughout the experimental work according to the intensity of solar radiation flux incident, the relative humidity, the stage of plant growth, the intensity of tomato plants per square meter of greenhouse-ground, and the type of greenhouse cover. Although cold air just leaving the evaporative cooling system for both greenhouses was at the same temperature, the interior air temperatures of both greenhouses were varied from one to another throughout the air stream. The first greenhouse (G1) increased the temperature of cold air just leaving the cooling system by $3.86{ }^{\circ} \mathrm{C}$, while 
the second greenhouse $(\mathrm{G} 2)$ increased the interior air temperature by 5.46 ${ }^{\circ} \mathrm{C}$. This difference $\left(1.6{ }^{\circ} \mathrm{C}\right)$ was due to the variation in intensity of solar radiation flux incident inside the two greenhouses, which was converted into thermal energy. As the exterior relative humidity is decreased and outside dry-bulb temperature exceeded $36{ }^{\circ} \mathrm{C}$, the wet-bulb depression and the saturation pressure increased and thus, the vapor pressure decreased making the evaporative cooling system more efficient and vice versa. The wet-bulb depression $\left(\mathrm{T}_{\mathrm{wd}}\right)$ was plotted against relative humidity (RH) as shown in Fig. (6). Regression analysis revealed a highly significant linear relationship $(\mathrm{P}<0.001)$ between the two parameters. The best fit equation relating the wet-bulb depression $\left(\mathrm{T}_{\mathrm{wd}}\right)$ to the exterior relative humidity (R.H.) was:

T w d $=27.886-0.4533$ (R.H.) $\quad, \quad[r=0.993]$

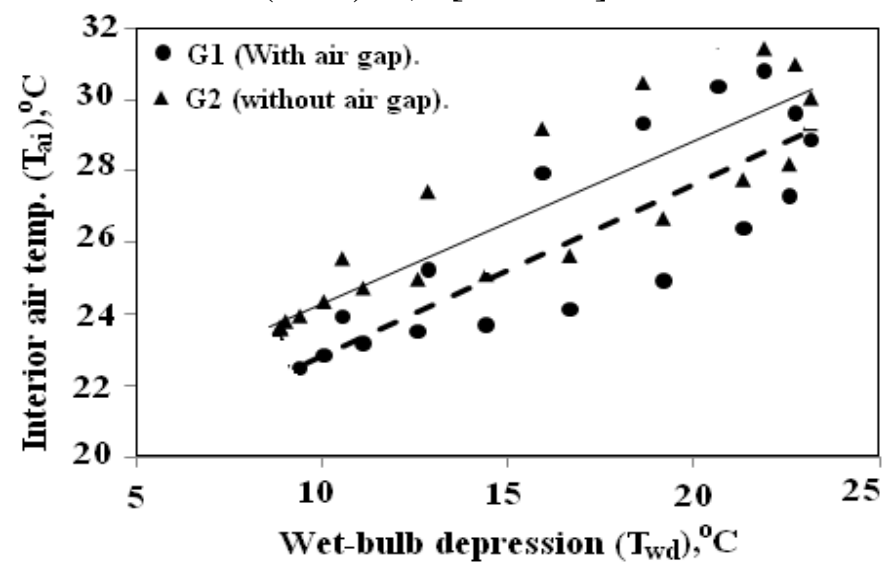

Fig. (5): Interior air temp. of greenhouse $\left(T_{a i}\right)$

versus wet-bulb depression $\left(\mathbf{T}_{\mathrm{wd}}\right)$.

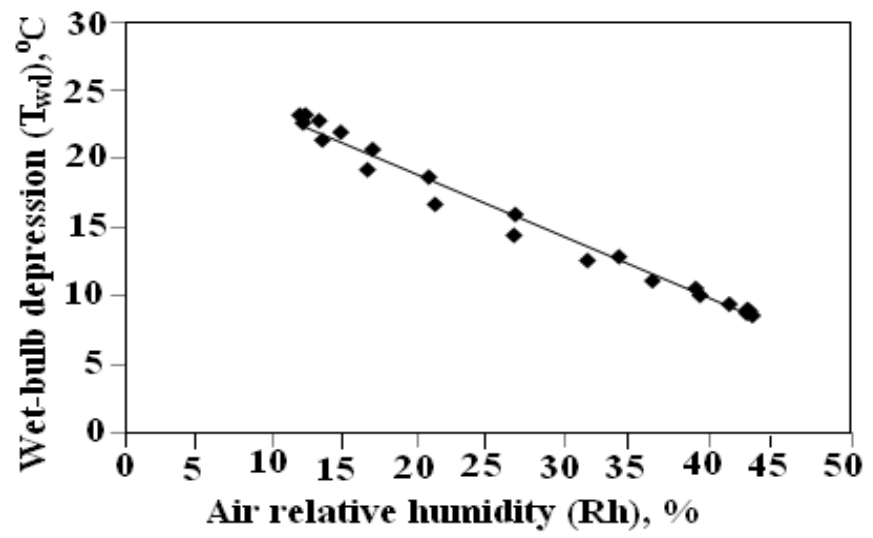

Fig. (6): Wet-bulb depression ( $\left.T_{\text {wd }}\right)$ versus air relative humidity (RH). 
3. Air temperatures: Figure (7) shows the relationship between the ambient air temperature $\left(\mathrm{T}_{\mathrm{ao}}\right)$ and the interior air temperatures of both greenhouses (Tai). It's clear that, both trends of interior air temperatures for the two greenhouses were blow the ambient temperature curve. Also, the minimum temperatures appeared with the first greenhouse (G1), due to the effect of using double layers with an 8-cm air gap of polyethylene, shading and the effectiveness of cooling process. The maximum differential data was obtained at 2 pm by $12{ }^{\circ} \mathrm{C}$ to $14{ }^{\circ} \mathrm{C}$ between exterior ambient temperature $\left(\mathrm{T}_{\mathrm{ao}}\right)$ and interior air temperatures of greenhouses $\left(\mathrm{T}_{\mathrm{ai}}\right)$. Multiple regression analysis revealed a highly significant linear relationship $(\mathrm{R}=0.989 ; \mathrm{P}<$ 0.001) between the ambient air temperature and effectiveness of evaporative cooling system. Finally, we can say that, the greenhouse covered with double layers of polyethylene - separated with 8-cm air gap (G1) mainly increased the effectiveness of cooling process, and this caused to decrease the interior air temperature of the greenhouse by $2{ }^{\circ} \mathrm{C}$ to $3{ }^{\circ} \mathrm{C}$ approximately. This difference may be explained by the fact that the optimum air temperature surrounding the tomato plants enhanced and increased the absorption rate of nutrient elements (which influenced the increasing of fruit set rate throughout the experimental work), photosynthesis process, and building of carbohydrates.

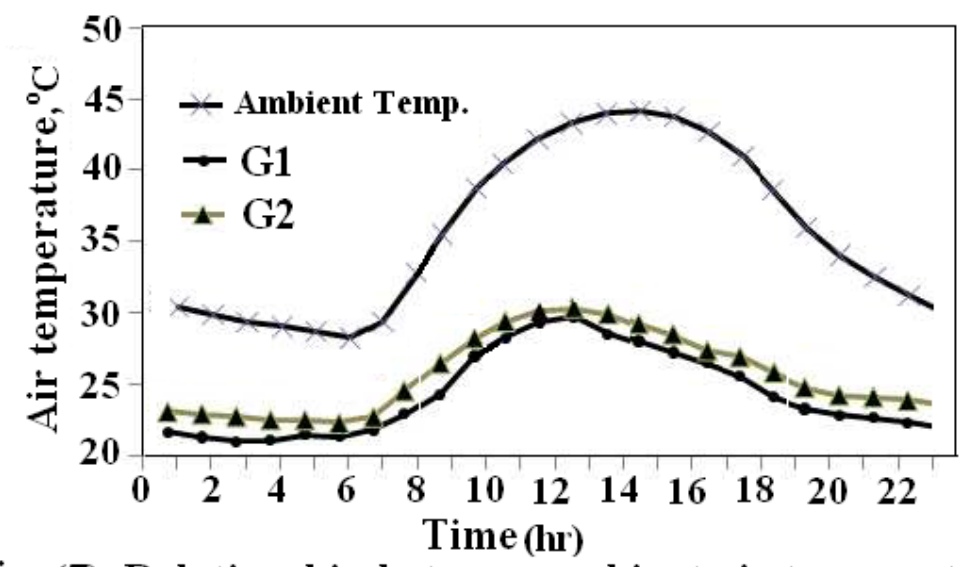

Fig. (7): Relationship beteewn ambient air temperature and interior air temperature of grenhouses. 
4. Growth and quality of tomato: Data was recorded weekly from the first to the final stages of the experimental period $\left(15^{\text {th }}\right.$ May to $15^{\text {th }}$ August, 2012) in plant length and yield of tomato. The obtained data appeared highly significant differences among the treatments for both greenhouses. On the other hand, the difference in stem length of tomato plants varied from one week to another throughout the growing season as shown in Fig. (8). It's clear that, the greater stem length was obtained from the first greenhouse (G1) because the interior air temperature of this greenhouse (G1) was around the optimum temperature $\left(25{ }^{\circ} \mathrm{C}\right)$ required for better growth, particularly at the critical period (from 10 am to $3 \mathrm{pm}$ ) of the day-time (as shown in Fig.7). It also clears that, the weekly average rates of stem length of plant for the two greenhouses (G1 and G2) were 15.5$\mathrm{cm} /$ plant/week and $13.9-\mathrm{cm} /$ plant/week, respectively, (Fig. 7). Thus, the first greenhouse (G1) increased the average rate of vegetative growth by $11.5 \%$ as compared with the second greenhouse (G2). This difference may be explained by the fact that, the optimum internal air temperature of greenhouse surrounding the tomato plants enhances and increases the absorption rate of nutrient elements, photosynthesis process, and building of carbohydrates. Consequently, as the green areas of leaves increased due to increase of vegetative growth rate, the biochemical processes increased, making the process of photosynthesis more efficient.

The interior air temperature of the greenhouse played a vital role not only for tomato vegetative growth, but also in influencing the vitality of seed insemination and, consequently, the number of fruit per plant. As the interior air temperature of the greenhouse increased over $32{ }^{\circ} \mathrm{C}$, the death rate of seed insemination increased, and thus, the fruit decreased making the crop fruitful at a minimum level. Also, excess of greenhouse interior air temperature commonly caused loss in stem strength, and area of leaves, delay in flowering, reduce fruit size, and increase in pathogenic organisms. Due to all of these reasons discussed above, the total fresh yield of tomato crop for both greenhouses (G1 and G2), was $416.2 \mathrm{~kg}$ (5.20 kg/plant), and $309.7 \mathrm{~kg}(3.87 \mathrm{~kg} / \mathrm{plant})$, respectively, as shown in Table (3). Consequently, the greenhouse covered by double layers of polyethylene with $8-\mathrm{cm}$ air gap (G1) was more productive than the other one covered with double polyethylene sheets stick to each other (G2). 
Although both of greenhouses (G1) and (G2) were covered with the same cover, greenhouse (G1) was found to be more productive because its cooling system had greater cooling effectiveness than the cooling system of greenhouse $(\mathrm{G} 2)$. The differences between mean fresh yields of tomato crop were highly significant with a probability of 0.99 . Analysis of variance for tomato fresh yield revealed that, the $\mathrm{F}$ ratio were significant ( $\mathrm{P}<0.001$ ). This clearly means that, cooling the interior air of the greenhouse particularly at day-time, especially during the summer months affecting significantly and positively the fresh yield of tomato crop.

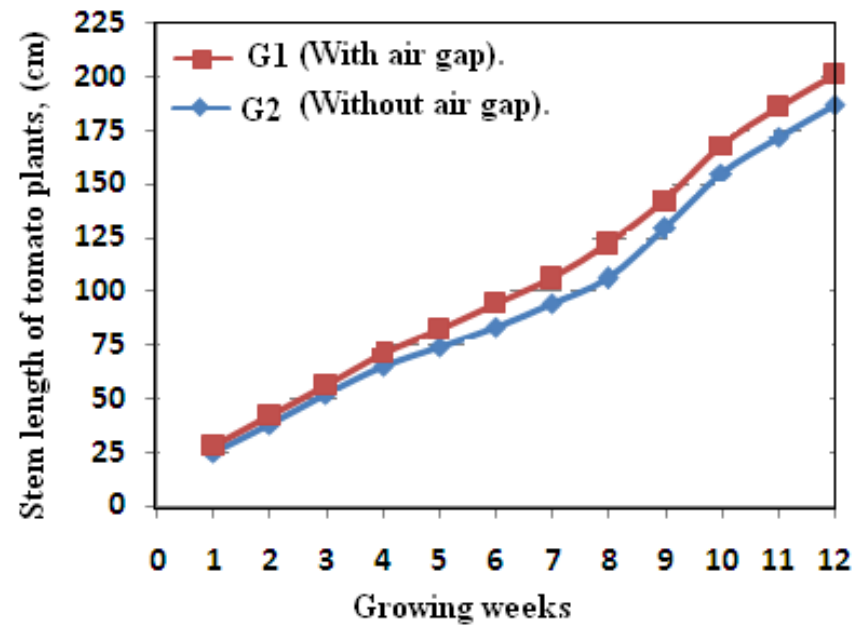

Fig.(8): Relationship between height of tomato plants and growing season for both greenhouses.

Table (3): Fresh yield of tomato under the two greenhouses for the summer month's treatments, 2012

\begin{tabular}{|c|c|c|}
\hline \multirow{2}{*}{ Treatment } & \multicolumn{2}{|c|}{ Fresh yield of tomato crop, $(\mathrm{kg})$} \\
\cline { 2 - 3 } & Average yield/plant & Total yield \\
\hline First greenhouse (G1) & 5.20 & 416.2 \\
\hline Second greenhouse $($ G2) & 3.87 & 309.7 \\
\hline
\end{tabular}

\section{CONCLUSION}

The results of this experimental work appeared that the greatest value of cooling effect $\left(11.86^{\circ} \mathrm{C}\right)$ and effectiveness of evaporative cooling system $(73.85 \%)$ were achieved inside the first greenhouse (G1), which covered 
by double layers of polyethylene with $8-\mathrm{cm}$ air gap, whereas, the cooling effect $\left(9.19^{\circ} \mathrm{C}\right)$ and effectiveness of cooling system $(67.57 \%)$ occurred inside the second greenhouse (G2), which covered by double layers of polyethylene without air gap. The first Greenhouse (G1) increased the temperature of cold air just leaving the cooling system by $3.86{ }^{\circ} \mathrm{C}$, while the second greenhouse (G2) increased the interior ambient air temperature by $5.46{ }^{\circ} \mathrm{C}$. Thus, the first greenhouse (G1), on the average, increased the rate of vegetative growth by $11.5 \%$, and fresh yield of tomato crop by $34.39 \%$ comparing with the second greenhouse (G2).

\section{REFERENCES}

Abdel-Galil, H. S. (2009). Effect of poly-greenhouse shading ratios on germination and yield of tomato under Fayoum depression climatic conditions. The $17^{\text {th }}$ Annual Conference of the Misr Society of Ag. Eng., 28 October 2010. Vol. 27 (4): 2048 - 2068.

Abdel-Ghany, A. M. ; Ishigami, Y. ; Goto, E. and Kozai, T. (2006). A method for measuring greenhouse cover temperature using a thermocouple. Biosystems Engineering 95 (1), 99-109.

Al-Amri, A. M. (2000). Comparative use of greenhouse covers materials and their effectiveness in evaporative cooling systems under conditions in eastern province of Saudi Arabia. Agricultural Mechanization in Asia, Africa and Latin America. 31(2):61-66.

Alhamdan, A. M. and Al-Helal, I. M. (2009). Mechanical deterioration of polyethylene greenhouses covering under arid conditions. Journal of materials processing technology 209: 63-69.

Al-Helal, I. M. (2007). Effects of ventilation rate on the environment of a fan-pad evaporative cooled, shaded greenhouse in extreme arid climates. Applied Engineering in Agriculture. ASABE, MI. USA. Vol. 23(2): 221-230.

ASHRAE, (1989). ASHRAE Handbook and Product Directory Fundamentals. American Society of Heating, Refrigerating and Air-Conditioning Engineers. Inc. New York. 
El-Batawi, I. E.; Mohri, K. and El-Rayes, A. (2004). Air temperature predication model to control heating in a germination greenhouse under Egyptian conditions. The $12^{\text {th }}$ Conference of Miser Society of Agric. Eng., 4-5 October 2004: 97-106.

Elsner, B. V.; Briassoulis, D.; Waaijenberg, D.; Mistriotis, A.; Zabeltitz, Chr. Von.; Gratraud, J.; Russo, G. and SuayCortes, R. (2000). Review of structural and functional characteristics of greenhouses in European Union countries: part i, design requirements. J. agric. Engng Res. 75, 1-16.

Heinemann, P. H. and Walker, P. N. (1987). Effects of greenhouse surface heating water on light transmission. Transactions of the ASAE, Vol. 30 (1): 215-220.

Kenneth, H.; Richard, S. and Charles, W. (2005). Budget for greenhouse tomatoes, Extension Service of Mississippi State Univ., Cooperating with U.S. Dept. of Agric. Publication 2257.

Lau, A. K. and Staley, L. M. (1989). Solar radiation transmission and capture in greenhouses. Can. Agric. Eng. 31: 204-214.

Nelson, V. P. (1990). Greenhouse operation and management. Third Edition, A Reston Book, Prentice-Hall, Inc. Englewood cliffs, New York, USA, 598 pp.

Papadakis, G. M. M.; Meneses, J. F. and Boulard, T. (1996). Measurement and analysis of air exchange rates in a greenhouse with continuous roof and side opening. J. of Agric. Eng. Research, 63, 219-228.

Takakura, T.; Manning, T. O.; Giacomelli, G. A. and Roberts, W. J. (1994). Feed forward control for a floor heat greenhouse. Transactions of the ASAE, Vol. 37(3): 939- 945.

Wikipedia, the free encyclopedia (2007). Solar greenhouse (technical). http://en.wikipedia.org/wiki/solar_greenhouse_(technical). 


\section{الملخص العربيى}

\section{أداء صوبة بلاستيكية ذات غطاء مزدوج من البولى ايثيلين بينه فجوة هو ائية}

\section{حمدى سالم السيد عبد الجليل* منيل}

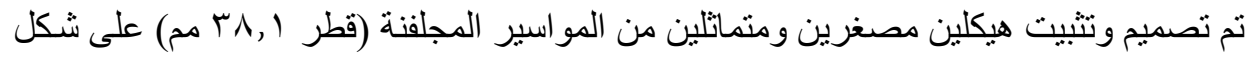

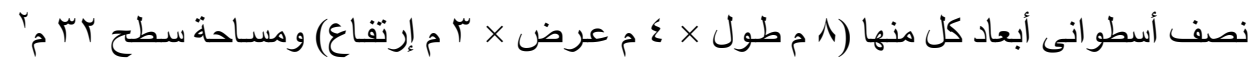

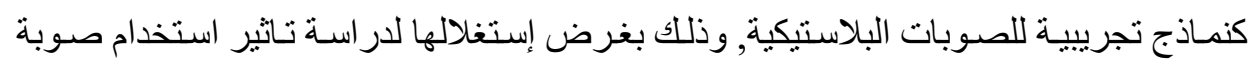

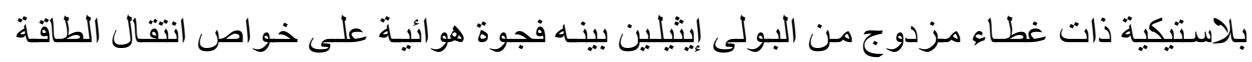

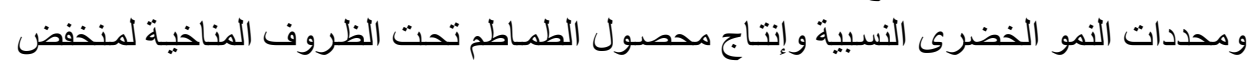

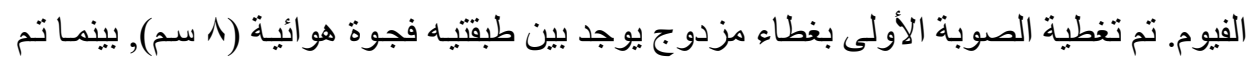

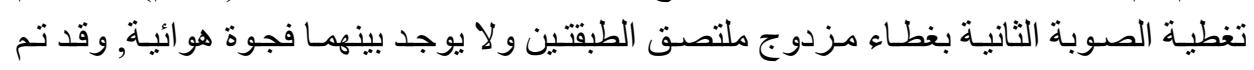

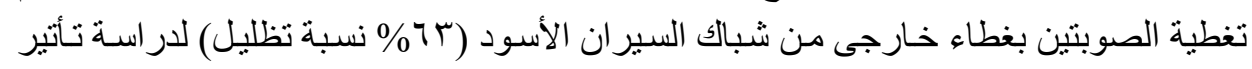

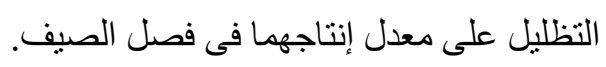
وقد أوضحت النتائج مايلى:

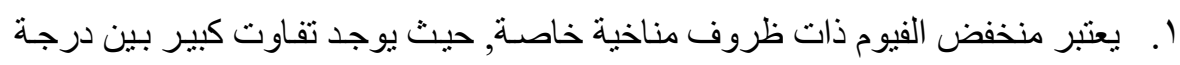

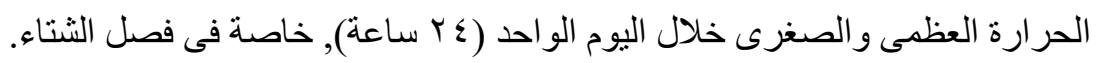

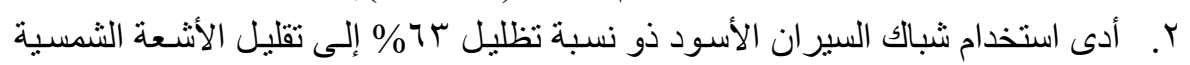

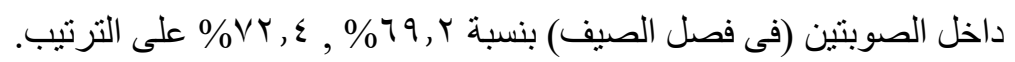

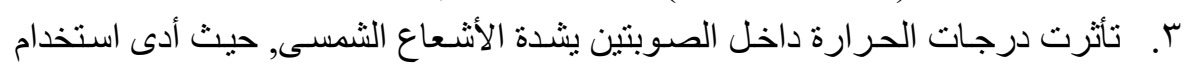

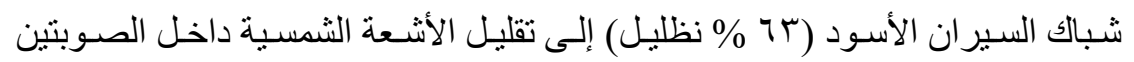

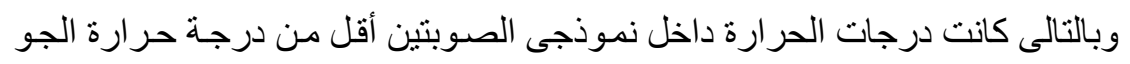
المحيط فى فصل الصيف (مع التحكم في عملية التهوية أنثاء ساعات النهار ).

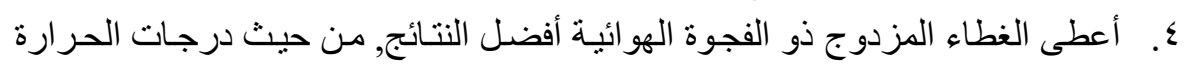

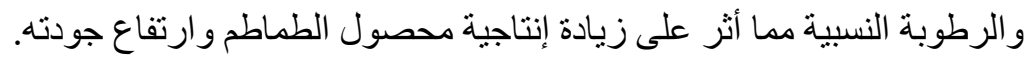

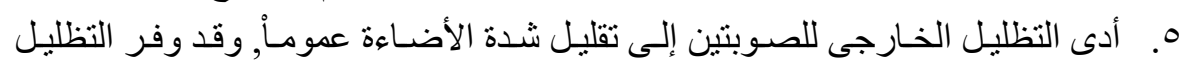

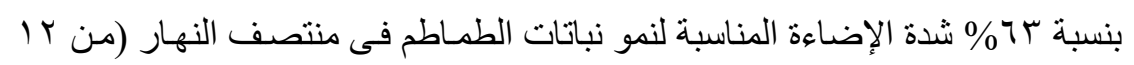

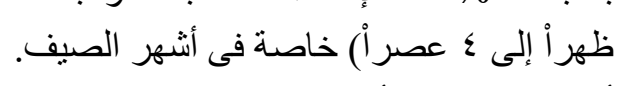

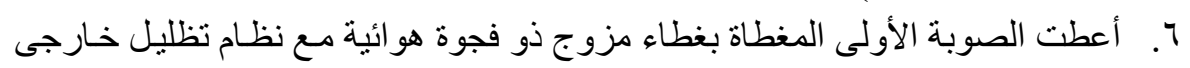

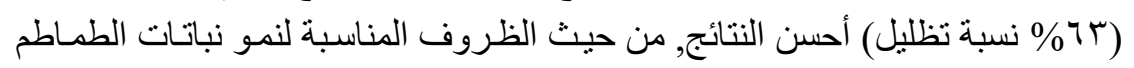

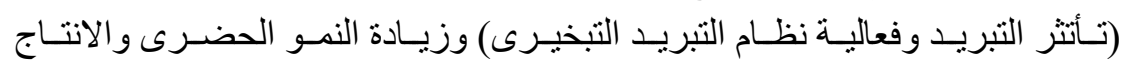

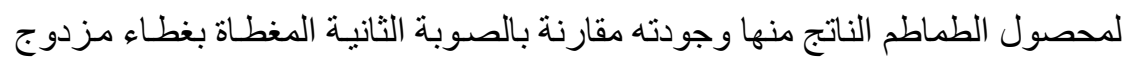
ملتصق (بدون فجوة هو ائية) ونفس نظام التظليل الخارجى. 